New Scholars Forum

\title{
DISCURSIVE FORMATIONS AND THE AMBIVALENT NATION IN GINA APOSTOL'S THE REVOLUTION ACCORDING TO RAYMUNDO MATA
}

\author{
Jillian Joyce Ong Tan \\ Columbia University, New York
}

\begin{abstract}
Gina Apostol's The Revolution According to Raymundo Mata brings to the fore a multicontested textual space that not only politicizes the act of reading, but more importantly, engages in a form of nation-building or imagining. The paper will demonstrate through a two-prong analysis of form and content that this novel utilizes postmodern modes of articulation such as parody, intertextuality, and a non-sequential temporal narrative in order to examine knowledge-productions, politics of representation, agency, and nationhood that have become immanent and critical in the emerging and rapidly-developing field of theoretical discourse that seeks to illuminate Philippine postcoloniality. It will also be argued that postmodern forms, which are premised upon diffusion, multiplicity, and the ambivalence of meaning render the notion of the Philippines to be equally ambivalent and diffused. Whether such re-imagining or re-configuring of the nation is advantageous or not is left for the reader to decide. The critical works of Linda Hutcheon, Homi Bhabha, and Benita Parry will serve as departure points for the analysis.
\end{abstract}

\section{Keywords}

historiographic metafiction, narrative, paratexts, parody, performative, Rizal

\section{About the Author}

Jillian Joyce Ong Tan is currently pursuing an MA in English and Comparative Literature at Columbia University, New York. She graduated last 2012 from the Ateneo de Manila University with a double-degree in Management and English Literature. 


\section{(Re)placing History and the Forging of Identities}

THE STUDY OF PHILIPPINE HISTORIOGRAPHY is a particularly thorny endeavor, polarizing and mired with conflicting purposes. History is, after all, written with an ideological standpoint in mind. Central, however, to all the variegating discourses on Philippine historiography is José Rizal whose life and works have become the foundation through which this country's nation-space has been imagined and configured. His two novels, Noli Me Tangere and El Filibusterismo, have been universally acknowledged as portents and catalysts of the Philippine Revolution. Such identity-formations and knowledge-productions arguably represent a desire to create an indissoluble bond among Filipinos, united by their admiration for Rizal and engendered by his imagination. Benedict Anderson, who calls Rizal "the father of Filipino Nationalism," suggests that the opening scene in Noli Me Tangere, which depicts a group of people from different socio-economic backgrounds discussing a party to be held that evening along Anloague Street "immediately conjures up [an] imagined community" (26-27). In spite of Rizal's undeniable influence, there is a looming inadequacy and lacunae that plague Philippine historiography, which stems from the little importance given to marginalized and ex-centric figures who have contributed as well as impeded the development of the Philippines as a nation.

Gina Apostol's The Revolution According to Raymundo Mata attempts to address this gap through a facetious treatment of historiography and the scholarship behind it. Apostol begins the novel by writing, "I knew no scholar, no text, not even a comic book that spoke of the Philippine War of Independence without disturbing solipsism or deeply-divided angst" (The Revolution 1). Through the novel's protagonist, Raymundo Mata, it attempts to search for an alternative configuration of both the past and a re-imagining or inscribing of the nation. In his seminal book Orientalism, Edward Said contends that "narrative is the specific form taken by written history to counter the permanence of vision" (240). Apostol has taken this statement to its extreme by choosing a narrator (Mata) who is night-blind, so what the novel, in fact, offers is an account of one of the most momentous occasions in Philippine History from a blind man's perspective. In so doing, The Revolution confronts historiography by placing at the forefront what has often been slipped under the rugs and sometimes deliberately ignored such as the testimonies of the marginalized sector of the community and, more importantly, the heroes' sheer humanity and its antecedent doubts and fears.

The novel unfolds through a series of collated diary entries arranged chronologically from when Mata was in primary school up to the start of the Philippine Revolution. The entries are divided into five parts: (1) A Childhood in Kawit; (2) Provinciano in the City; (3) Blind Man's Bluff; (4) The General in the Revolution; and (5) Aftermass. The diary ends abruptly because Mata was imprisoned for pilfering during the American occupation and subjected to regular bouts of torture. It can be assumed that it is in between those bouts of 
torture that Mata compiled and emended his entries. He died in jail and what remained was a medical bag filled with papers and other medical paraphernalia. Three women footnote the diary: Estrella Espejo, Dr. Diwata Drake, and Mimi C. Magsalin. Each, based on her specific subject-position, will compete with others in claiming to understand Mata and what his cryptic notes meant. Espejo suffers from an acute case of nostalgia, extreme patriotism, and panic attacks brought about by encounters with western products such as hamburgers. Characteristics of Espejo's hermeneutics include her unwavering loyalty to the pristine memory of Rizal, her predilection to see anything vaguely cryptic as an example of Katipunan Code (even though some of the entries are dated years before the founding of the secret organization), and her propensity to include personal anecdotes in her footnotes. She ends her preface with a remark that is not only paradoxical, but also highly uncharacteristic of a historian, "My surprise was great as I read on. That the storyteller is, I must admit, flawed, maybe mad, does not diminish my faith in his story. In fact, his madness amplifies its truth" (Apostol, The Revolution 2). Dr. Drake, a psychoanalyst from the "Mürkian School of Psychoanalysis," continues the editing of the papers when Espejo is confined in the hospital after a particularly life-threatening nervous breakdown. Considering herself a Midwestern mongrel who is "half-Filipino from my maternal grandmother's side," Dr. Drake regards the entries as the perfect supplement to her unfinished book tentatively entitled You Lovely Symptoms: The Structure of the Filipino Unconscious, Not Really a Langue or a Parole. She writes in her addendum:

Here was a document worth my while: filled with misconstructions of the ego and the malapropisms of time, affections unnarcoticized (banyan trees get more time than the Cry of Balintawak - genius!), autistic lists, moving digressions, classic psychopathologies of the tongue (typical of the Filipino, who has an irritating penchant for puns). (Apostol, The Revolution 10)

Among the three, Magsalin, the translator, is perhaps the most ambivalent and selfreflexive. She poses a question in Entry \#21 when the derogatory word "indio" was used by Mata, "So what then should a translator do? Take on the Spanish prejudice by using the denotative term 'indio'? Or translate it inaccurately as 'Filipino'? A tragic agon of colonial pain lies dramatized in quotation marks. I took the path of least resistance and just footnoted" (Apostol, The Revolution 98). Magsalin is also the last person to see the Mata Papers in its original form. The entries are now suspected to be lost and possibly irrecoverable due to a typhoon that struck the Philippines.

Such a hypertextual version of History is enabled by Apostol's appropriation of the postmodern form called "historiographic metafiction." Postmodern critic Linda Hutcheon characterizes historiographic metafiction "as a kind of fiction that is at once metafictional and historical in its echoes of the texts and contexts 
of the past" (Historiographic 3). It attempts to show History as an ideological construct that often materializes through a violent restructuring or as a result of a deliberate emplotment. Furthermore, it enables the reader to recognize "not only the inevitable textuality of our knowledge of the past, but also both the value and limitation of that inescapably discursive form of knowledge" (Historiographic 8). Summarily, this form makes use of the strategic advantages of both historiography and fiction, hence, allowing the text to straddle worldliness and literariness respectively. It therefore eludes any notion of totality and undermines the singularity of History as one knows it.

Historiographic metafiction is a popular choice among Filipino authors and three of the four winners of the much-publicized Philippine literary contest sponsored by the Estrada government during the centennial anniversary of the nation's independence from Spain employed it as their literary form of choice. Such patriotic tendencies and artistic vision are, however, not always unequivocally celebrated. R. Kwan Laurel observes that Eric Gamalinda's My Sad Republic, Charlson Ong's An Embarrassment of Riches, and Alfred Yuson's Voyeurs and Savages "have only cut and pasted certain historical moments together, and have ignored history altogether" (60o). Whether it is justified or not, Laurel has read these novels as manifestations of the many problems that plague any engagement with History regardless of the liberty provided by historiographic metafiction. The question that begs to be asked is: Had The Revolution been published during the time of the Centennial awards, would Laurel have accused it of ignoring History altogether like Ong or trivializing it like Gamalinda? (Laurel 6oo)

The answer to the question posed above is not as resolute or as definitive as the one provided by Laurel. Apostol's numerous characters from different subjectpositions enable her to avoid reductive or homogenizing tendencies. Furthermore, Apostol also places the act of translation and interpretation at the heart of the novel. In an interview conducted by Daryll Delgado for Kritika Kultura, Apostol locates the burden of the Philippine postcolonial condition at the citizens' existence as "translated beings, footnotes within footnotes, grasped only by a series of mediations, braid upon braid of voices with relentless multiplicity" (Apostol, Interview 293). Perhaps, it is the acknowledgement of postcolonial Philippines's tenuous and often contradictory position that can deter Laurel from equating Apostol with her literary predecessors. To read The Revolution is therefore to encounter the nation "as it is written" at its moment of production, as it were, and to see it, as Bhabha writes in his introduction to Nation and Narration, "as a form of cultural elaboration (in the Gramscian sense)" and the locus of an "agency of ambivalent narration that holds culture at its most productive position, as force for 'subordination, fracturing, diffusing, reproducing, as much as producing, creating, forcing, guiding"' (3-4). Noticeably, the stance of Bhabha as well as the technique of Apostol show a denial of coherence and unification. The desire for an infinite space of production and meaning making is made manifest in the many 
loops within The Revolution and, to a certain extent, removes it from any material reality. At this point, it is important to note that one cannot conclude that The Revolution is plagued with the same problem as the Centennial winners, but the novel does raise several questions about the widening gap between the space of the literary production and its socio-historical basis.

Such questions necessitate an examination of both form (historiographic metafiction and its consequent formal manifestations) and content (the ambivalent imagination of a nation-space and the historical underpinnings or lack thereof in the novel). Before such an examination, it is important to note that The Revolution unfolds dialectically through the spatial analysis of the nation as recreated in the imagination of its characters and the temporal continuity or discontinuity that they have with the past. This dialectic gives rise to three critical questions: (1) In foregrounding the lives of ex-centric and their eccentricities as well as its farcical treatment of the Philippine revolution, what forms and structures of knowledge are impinged upon and consequently destroyed? (2) What kind of Philippine nation emerges from such an ambivalent narrative? (3) What is the politics behind a displaced historical account that only finds legitimacy and agency in a textual/ discursive space?

\section{Historiographic Metafiction and the De-Doxification of History}

In Hutcheon's The Politics of Postmodernism, she discusses some key postmodern literary devices that Apostol would use in the novel such as (1) paratextuality and parody; (2) intertextuality; and (3) the decentering of western metaphysical constants such as the "I" and the linear progression of time. These three techniques and motifs allow any postmodernist text to become self-conscious, self-contradictory, and self-undermining (Politics 1 ).

Paratextuality is a postmodern technique that functions through simultaneously effacing and asserting its own authority. Hutcheon classifies paratexts "as footnotes and the textual incorporation of written documents that simultaneously signals an authoritative referent while disrupting one's reading "of a coherent, totalizing fictive narrative" (Politics 81). Paratexts also produce the effect of doubling, a doubled narrative of the past in the present as it were (Politics 80). Furthermore, the insertion of historical documents can also be related to Brecht's alienation effect where "like the songs in his plays, the historical documents dropped into the fictions have the potential effect of interrupting any illusion, of making the reader into an aware collaborator, not a passive consumer" (Politics $84-85$ ). In the case of The Revolution, we have at least three levels of readings: (1) The editors reading Mata's Entries; (2) The reader reading Mata's entries; and (3) The reader reading the editors' reading of Mata. Here, what occurs is the conveying of agency not to 
the author/creator but to the reader, thus allowing the "free-play" of reading and interpretation.

Before presenting Mata's entries, Dr. Drake poses a caveat, "Filipino scholarship has an endemic originality: it is stained by passion. You will note a chronological set of querulous attachments ... Thus, enclosed herewith are the underbeams of the text's construction - a rumbling exegesis by email, anathema, and dyspeptic scrawl" (Apostol, The Revolution 31). With this begins the novel that attempts to rewrite History while simultaneously showing how the writing is being done. Let us look at the second entry in the novel, which is dated January 20, 1872 (the day of the Cavite Mutiny). Mata writes, "I followed shit. I mean suit 30313233 34" (Apostol, The Revolution 39). The following are excerpts of the footnotes that followed after this line:

30 The pun on shit and suit is mine, but it matches the vulgarity of the original. Kitchen Spanish as Rizal called it... (Trans. Note)

31 ...it's sad to note that despite their heartrending bond, the friends [Blumentritt and Rizal] spent only around forty-eight hours, max, in each other's companyand so we have perhaps a fine inspired hypochondria to thank for the copious, homoerotic correspondence that survives. In one of those endless letters, Rizal made a matter-of-fact list of Filipino languages to satisfy Blumentritt's scholarly questions; next to Cavite, Rizal simply noted: español de cocina (Trans. Note) 32 Homoerotic? Shame on you, Mimi C.! Just because you have the power of the pen in the modern age does not mean every word is a phallic orgy...May Rizal's heterosexual hex vex you from Banahaw! (Estrella Espejo)

33 Mimi C. did not say Rizal was gay; she said the letters were homoerotic. (Dr. Diwata Drake)

34. Same difference. (Estrella Espejo)

(Apostol, The Revolution 39)

In a span of five footnotes and a single line from a diary entry, Apostol unsettles the traditional perception of Rizal as a polyglot scholar (showing that the hero himself has certain biases), illustrates Espejo's myopic view of the national hero, and questions the reliability of the translator. This is the kind of scholarly engagement that often occurs behind closed doors, and by showing it to the readers, Apostol ruptures the validity of historical narratives and the authority of footnotes. In doing so, she not only transfers agency to the reader, but more importantly, unsettles the hegemonic and authoritative nature of academic scholarship. The participative nature of the text also implies that the reader is integral in completing the work's meaning, and he or she must simultaneously interpret both footnotes and the entries. One can see that the questioning of the archival documents, which is one of the functions of a paratext, is not simply a matter of invalidating the past, but of reminding us that in reading History, one must not be a passive but a self-reflexive reader. 
Paratexts are therefore used in the novel as a democratization of the text and as a limning of history-as-construct. As mentioned earlier, Philippine historiography has been beset by polarizing scholarship, and an important example of this is whether a scholar was for the revolutionary majority in the tradition of Reynaldo Ileto and his Pasyon and Revolution, or for Nick Joaquin and his Hispanized Filipino elite as illustrated in The Portrait of the Artist as Filipino (Hau 101). Through the paratexts in The Revolution, one sees a negotiation of both ends of the spectrum. Raymundo Mata is educated in Ateneo Municipal, the same school that Rizal attended. This university has historically been perceived as the school for the elite with the presence of the learned and liberal Jesuit priests who taught there. Dr. Diwata Drake and Mimi Magsalin are US-based intellectuals. In contrast to these figures is Estrella Espejo, a graduate of the University of the Philippines, an institution well-known for supporting student activism and land reform. The clashing of Marxist ideologies in the figure of Espejo (note her previously mentioned battle with a hamburger) and Lacanian psychoanalysis in the figure of the hybrid Dr. Drake shows the kind of battleground that the Philippines continuously finds itself in. Ironically, it is often Espejo who castigates Mata for his actions such as stealing Rizal's draft of Makamisa when she should feel more sympathetic to his reactive and reactionary nature. After all, the purloining of Rizal's Makamisa suggests a kind of revisionist writing, a writing that came from the margins as it were. On the other hand, Dr. Drake and Magsalin who represent the institutions of the United States are always sympathetic to Mata when his presence threatens the heroic, almost mythicized nature of José Rizal. One must remember that the Americans promoted Rizal over Andres Bonifacio because they found a convenient legitimization of their colonial policy "in Rizal's philosophy of education of the masses first before independence" (Agoncillo 160). Bonifacio's advocacy for armed resistance discomfited the Americans who harbored plans of assimilating the Philippine islands; thus, Rizal's pacifist stance led to his induction as national hero. The favorable reaction of Dr. Drake and Magsalin will be further explored in the latter part of this study.

Aside from paratexts, Apostol also employs parody. According to Hutcheon, parody works through "a double process of installing and ironizing, [it] signals how present representations come from past ones and what ideological consequences derive from both continuity and difference" (Politics 88). Essentially, the presence of parody through its ironic overtones and undertones allows one to both subvert and preserve History. Hutcheon further adds, "the politics of representation and the representation of politics frequently go hand in hand in parodic postmodern historiographic metafiction" (Politics 99).

Take, for example, Entry \#30 when Mata adds his own emendations to the multiple versions of Dr. Pio Valenzuela's account of their trip to Dapitan. Espejo notes, "Pio Valenzuela's alternate versions of this trip are available in at least three forms, each version providing a perplexing pall upon the next" (Apostol, The Revolution 172). In 
this entry, Mata criticizes Valenzuela for being a pretentious and boring wanna-be revolutionary who exaggerates Mata's eye disease to entertain ladies. He also informs the reader that the doctor is in fact a book-peddler who is perhaps more inclined to literary embellishments than facts. Mata bitterly comments:

I bet a hundred pesos the doctor barely mentioned my name in his odious confessions to the Spaniards, the scoundrel, and instead of being a major actor in a historic drama, I'm instead a minor detail in a hysteric's act, doomed to molder in history books as some obscure blind man with a useless passion in the company of that lying doctor Don Pio Valenzuela, betrayer of the revolution..$^{31}$ Whereas, in truth, what could history have become, if only someone had asked me? (Apostol, The Revolution 177)

Indeed, what could History have become, if only someone had asked Mata? The accounts of Dr. Valenzuela have been used by the Spanish prosecutors to indict Rizal for treason and, had more investigations been conducted, they will realize that Mata has a very different portrayal of the events in Dapitan. This particular entry sets up the eventual meeting between Mata and Rizal where the latter is as far from a revolutionary as anyone can be. The testimonies of Dr. Valenzuela seem to suggest a desire to project onto Rizal his own authorial tendencies as well as to make a name for himself as the man who convinced the hero to support the impending revolution.

In addition, the propensity of Dr. Valenzuela to politicize, going as far as making up a story that Mata was struck as a child by a wayward friar, suggests the inextricably political nature of any representation. He takes it upon himself to speak for the subaltern Mata who "lisped and preened and curtsied and worst of all, accepted all of Dr. Pio's lies" (Apostol, The Revolution 176). It is very clear in this part that, to a certain extent, the ilustrado class as represented by Dr. Valenzuela also contributes to the marginalization of people who belong to a lower socioeconomic class such as Mata. In contrast to this is the politics of emancipation in Mata's "counter-memoir," and although it is rather belated, Mata is at least able to speak for himself. His narrative which provokes its own version of pathos opens up the space for an alternative reading of History, one that not only came from the margins but destabilizes the primacy of what has been considered a factual account of the past.

The last discursive technique that Apostol uses is intertextuality. Roland Barthes and Micahel Rifaterre believe that intertextuality "replaces the challenged author-text relationship with one between reader and text, one that situates the locus of textual meaning within the history of discourse itself" (qtd. in Hutcheon, Historiographic 7). Hutcheon adds, "[intertextuality] demands of the reader not only the recognition of textualized traces of the past, but also an awareness of what has been done-through-irony to those traces" (Historiographic 8). Apostol 
achieves this by integrating The Revolution with Makamisa. It was only recently, in fact, that the Rizal historian Ambeth Ocampo discovered a draft of Makamisa. For several decades, the twenty-page text was mistakenly labeled as a draft of the Noli Me Tangere since some names of the characters were the same (Ocampo 19-20). As mentioned in the summary given earlier, the last chapter of The Revolution is "Aftermass," which is the English translation of "makamisa." When Mata visits Rizal in Dapitan, he was disappointed with the kind of life the hero was living over there. Considering his meeting with Rizal as the highlight of his otherwise uninspired career as a revolutionary, his entries revealed a dismayed Mata. He asks the hero about the rumored third novel only to be rebuffed with a vague answer. Depressed over the lack of revolutionary/authorial commitment in Rizal as well as the doctor's unfavorable diagnosis of his eye disease, he takes a walk and stumbles upon a hut. To his delight, he sees a sheaf of paper that appears to be the draft of Rizal's sequel to the El Filibusterismo; he then proceeds to steal the draft and brings it back with him to Manila. In "Aftermass," each paragraph of Makamisa as compiled by Ocampo is juxtaposed with a narrative written by Mata, either typed in the backside or in an altogether new sheet of paper. Rizal's text is in regular typeface while Mata's emendations are italicized. One example of the latter's addition is to include "typist" as the profession of Ysagani, which is unsurprisingly also Mata's job. What becomes very interesting is when the first diary entry of Mata corresponds with the final regular typeface paragraph in this part; thus, the novel follows a circular structure ending where it began. The ending also raises doubts on both Makamisa as well as the character of Raymundo Mata. Readers will notice that the italicized parts are indistinguishable from the original transcript of Makamisa, the savant/plagiarizing Mata can copy Rizal's literary style with perfect precision, which is why Magsalin had to emphasize the part by italicizing it. Could it be possible that what we consider as Rizal's third novel was actually written by a forgotten and blind member of the Katipunan? How would that change our reading of Makamisa or even Rizal's two prior novels?

By forcibly implicating himself in Makamisa, Mata shows that the peripheral and the central can coexist without negating each other. In the more recent past, because of Rizal's stature as a national hero, his novels have become almost untouchable. Local readers have a tendency to accept traditional criticism of his work as manifestations of nationalist sentiments, and to a large extent, that is really one of the novels' overarching projects. However, there is much more to Rizal and his works than anti-friar sentiments. Apostol believes that this specific chapter does not only benefit her own novel, "And of course I cheated since Rizal had already given me words, but you have to understand Rizal must also gain from this juxtaposition. That's why multiplicity is good" ("Interview" 296). What, then, does Rizal gain from this unseemly interruption of his unfinished novel? My own sense is that Rizal's text gains by a widening of his works' hermeneutic field as well as a more enlightened view of Rizal as both national hero and author. Intertextuality 
functions as a way to signal the ineluctable influence of the past and pays homage to it by removing it from the archives of historical contingencies and repositioning it at the forefront of contemporary discourse. Discourse is also enabled by the presence and influence of deconstruction as a philosophical method.

In the event that Derrida calls a "rupture ... when the structurality of structures" were examined and investigated, a realization occurs, which is the absence of the center, resulting in the conclusion that "everything [becomes] discourse ... the original or transcendental signified, is never absolutely present outside a system of differences (353-54). By questioning and proving invalid the center that had historically taken on various forms such as Truth, telos, time, and even the West or the Occident, counter-discourse can finally emerge. What has traditionally been marginalized or defined as (ex)centric can now question the very existence and legitimacy of the binaries that have subjugated them.

The Revolution also problematizes time especially as an intersection of memory. Although the diaries are arranged chronologically, the reader is often unsettled by certain entries leaping into the future. Mata's concept of his age also varies, depending on the entry one is reading. An example of a flash-forward occurs in Entry \#24 dated 1892, almost a decade before the American occupation and Mata's imprisonment at Bilibid. In this entry he writes, "even laid out wounded and naked in the dungeons of Bilibid, he turned to me with the same," suggesting either that he foresaw his own imprisonment or that he was writing in retrospect. The Bilibid entry along with Mata's mutable notion of his age situating the years of his birth between 1862-1872 makes locating the period in which he wrote his entries difficult. One possibility is that Mata kept a notebook growing up and heavily edited these entries while he was already in prison to suit the kind of project he had in mind. Although it does make the narrator unreliable and puts the veracity of the entries in doubt, the retrospective editing of Mata seems to be the most probable option. The lack of dates on the entries with two exceptions (one dated on the day of the Cavite Mutiny and the other during the year Rizal began writing Noli Me Tangere) is further proof that the completed entries were written in retrospect, with Mata remembering only the more significant dates.

The novel's amorphous notion of time as existing both within and outside the actual narrative undermines the facticity and legitimacy of History. Temporal constraints, that is, time as a ruling or guiding principle, is often used by History to validate its claims, but this text refuses to be contained into one specific temporal period. The novel traverses the past through Mata's recollections, portends the future of the Philippine revolution through Mata's childhood caricatures of the various people who will dictate its course, and deals with the present through the three editors. The Revolution is a novel that is defined by its excess and slippages while continuously deconstructing itself along the way. By pointing towards its own constructed/fictive nature, the novel pushes the reader to question historiography whose basis is largely dependent upon first-hand narratives such as diaries. 
The unsettling of the past and the questioning of History, however, cannot be completed without providing a restructuring. The next question and perhaps the most important one is: what kind of nation emerges from the past that is deconstructed and reconstructed by Apostol? It seems that such a nation will be defined by ambivalence because it is still founded upon a text and another author's imagination. The succeeding part will attempt to provide an answer, however provisional, to this question. Also, a survey of Apostol's politics (or lack thereof) will be examined.

\section{The Ambivalent Nation and After Apostol}

The space that is opened by Derrida's rupture has been appropriated by various critics of minority discourse such as the pre-eminent postcolonial theorist, Homi Bhabha, who visualizes this decentering gesture as "a space of translation: a place of hybridity, figuratively speaking, where the construction of a political object that is new, neither one nor the other, properly alienates our political expectations, and changes, as it must, the very forms of our recognition of the moment of politics" (Location 37). Derrida's deconstruction of the center becomes a space-clearing gesture, allowing for what Bhabha calls the "third space." This space is imperative in any postcolonial or minority discourse because "through unrepresentable in itself, [it] constitutes the discursive conditions of enunciation that ensure that the meaning and symbols of culture have no primordial unity or fixity; that even the same signs can be appropriated, translated, rehistoricized and read anew" (Location 55).

Based on an examination of the literary techniques employed in The Revolution, one can see a clear trope of ambiguity emerge. The multiple perspectives and the plethora of voices impede any cohesive reading of the text. The critical advantage of The Revolution's ambiguity can be more clearly seen through the application of Bhabha's notion of the "the third space of enunciation." Apostol, in fact, conceives the novel in a very similar way to Bhabha: "[The Revolution] was planned as a puzzle: traps for the reader, dead-end jokes, textual games and unexplained sleights of tongue" (The Revolution 290). This ambivalence is clearly something that Apostol celebrates or at least remains faithful to throughout the entire novel.

Finding the loci of the novel in a hybrid site changes the epistemological relationship in the novel from one with a clear object of inquiry to a field where signifying systems are repeatedly diffused. Dr. Drake articulates this liminality in her epitaph:

So the document seems not one but two-or who knows three: one a waspish intertext of witches, another a disarmed combatants' confession of misadventure, and yet another (the most revolutionary of them all, perhaps) the 
abominable pulsing void in which the intramural wrangling and all that awful mess, the pasticciaccio brutto of voices, intersect and must converge (Apostol, The Revolution 273, emphasis mine).

This "abominable pulsing void," Bhabha believes, "is not self-contradictory but significantly performs, in the process of its discussion, the problems of judgment and identification" (Location 43). An example of this is how each of the three editors and other scholars interpret the ending of Mata's entries which mysteriously correspond to Rizal's third unfinished novel. Espejo believes that Makamisa and the entries of Mata are one and the same (Apostol, The Revolution 274). Others also believe that everything was simply the result of Mata's over-imagination while some believe that "Mata's memoir is a text within Rizal's recently discovered novel Makamisa" (Apostol, The Revolution 274-275). Dr. Drake, on the other hand, believes that such dexterity with literary and mimetic techniques could only be done by a "translator"; she then challenges Magsalin to produce the original text (Apostol, The Revolution 277). The Revolution ends with Magsalin's postcard written in code, "Mi noamla: ra puada vimgoes am at," which can be translated as "No miente: se peude confiar en el" or in English "It's not a lie: You can trust it" (Apostol, The Revolution 279). Indeed, the discovery of the Mata papers questions the very nature of Makamisa as well as Rizal's literary and nationalist aspirations. Everything hinges upon a text whether it is Rizal's, Mata's, or even, Magsalin's. One can never be certain of who is telling the "truth" and such an open-ended ending, ironically, leaves very little room for negotiation. Where does one stand in this void? Perhaps, the next part, which will discuss nationhood-as-discourse, can prove to be more enlightening.

In the chapter "Dissemination: Time, Narrative and the Margins of the Modern Nation," Bhabha elaborates on his notions of doubling in relation to a nation's people. This doubling occurs in between what Bhabha calls "the pedagogical" and "the performative." The former functions largely in the past through objective cultural significations while the latter deals with the present in the constant act of demonstrating its identity as a nation people (Location 208). Bhabha explains the process:

The scraps, patches, and rags of daily life must be repeatedly turned into the signs of a coherent national culture, while the very act of the narrative performance interpellates a growing circle of national subjects. In the production of the nation as narration there is a split between the continuist, accumulative temporality of the pedagogical, and the repetitious, recursive strategy of the performative. It is through this process of splitting that the conceptual ambivalence of modern society becomes the site of writing the nation (209). 
The Revolution splits the performative from the pedagogical in several ways. First, is the notion of the novel as in itself, performative. Prior to reading Rizal's Noli Me Tangere, Mata writes, "I will write a book into which my countrymen would see themselves as if in a mirror, or at least like the reflection of a drunk in a wasted glass" (Apostol, The Revolution 120). However, soon after this, Mata reads the Noli and reacts, "I cursed [Rizal] ... for doing what I hadn't done, for putting my world into words before I even had the sense to know what the world was ... I already felt the bitter envy, the acid retch of a latecomer artist ... a borrower never lender be" (Apostol, The Revolution 121). In this part, one is able to understand why the novel must necessarily be performative. For Mata, the presence of Rizal and his novel precedes reality and the hero's words shape the world for him. As such, he must constantly perform as the double of the hero who has already interpellated him. How could he be anything but the negative of Rizal? Dr. Drake observes the same thing, "Could it be said as well that from the Cavite Mutiny Jose Rizal begat novels, while Raymundo Mata begat shit?" (Apostol, The Revolution 44). The Revolution, therefore, performs as the mirror of Rizal's text, similar to the way Mata is Rizal's comic double.

However, Apostol is not content with merely the creation of a double, but makes the climax of The Revolution the long-awaited meeting between Mata and his idol, Rizal. In Entry \#33, the binary of the pedagogical and the performative collapses and what arises is a slippage in identity. Mata writes, "On Dapitan, if I were not careful, oblivion would swallow me up. Zamboanga was the end of the world: and there was nothing with all the pig-herding, coffee-planting, fishnet-hauling ... there was nothing to live for under its stricken stars" (Apostol, The Revolution 201). The first part ending at the colon echoes the well-known sentiments of Rizal as an exile, which explains why he applied to be an army medic in the Cuban War as part of the Spanish Army. On the other hand, the latter part seems to be the scathing and bitter remark of Mata over Rizal's lack of heroic display. In this conflated entry, the pedagogical Rizal seeks agency while the performative Mata struggles in the search for a transcendental historical signifier. Historically, this was provided by the mythic scholarship surrounding Rizal, which were premised upon larger-thanlife descriptions and anecdotes of his Messianic ability to heal people. Rufino, one of the men who accompanied Mata to Dapitan, is also extremely excited to meet Rizal and says to Mata, "He can walk on water, you know" (Apostol, The Revolution 179). It is only when Mata encounters Rizal in Dapitan that he realizes that the myth surrounding this hero is not only exaggerated but worse, not enough to satiate his longing for an identity. The first words he says to Rizal upon seeing him are, "Jesus Christ, you're short! Jesusmariosep, Jesusmaryjoseph. I was taller than Jose Rizal" (Apostol, The Revolution 190). Clearly, Rizal cannot live up to the expectations of grandeur, which Mata reserved for him.

Postcolonial theory often focuses on the colonial encounter alone, that is, the dynamics between the colonizer and colonized. However, one should also pay 
attention to the heterogeneous quality of the various subjugated identities who are often at odds with each other. A nation constantly undergoes the process of "dissemination" because of the conflict between the pedagogical and the performative (Bhabha, Location 212). This liminal existence of the nation-people becomes necessary in emancipating themselves from hegemonic ideologies such as those of bourgeois nationalism. Paradoxically, "the unity of a nation consists in the continual displacement of the anxiety of its irredeemably plural modern space" (Bhabha, Location 213) Simply put, the nation, like Lacan's concept of desire as continuously moving through an endless chain of signifiers, must perpetually look for a signifier that will reflect its identity as a nation.

Dr. Drake characterizes "nationhood" as a "jerky motion-more akin to awkward crablike lunges perhaps, sometimes backwards or sideways, at times forward" (Apostol, The Revolution 99). It is one that runs against homogenous space-time and in the same fashion as Jorge Luis Borges's "Garden of the Forking Paths" where there is the possibility of a series of time converging and diverging. The concept of a nation is problematized by Mata, himself: "To retrieve the illusion of wholeness for this random and sinking archipelago, this patchwork of bamboo-and-coconut planets speaking idly and in many tongues ... From this vantage, the notion of Filipinas was at best a fluke, or worse someone else's error" (Apostol, The Revolution 201-02). There is an entropic quality to the language of Mata in this section of the novel. This part comes right after the conflation of Mata and Rizal and seems to show that even the national hero had doubts over the country that he was going to die for. Such an ending seems to posit that the discourse of nationhood in this novel is actually ambivalent. What can possibly arise from an ambivalent text but an ambivalent nation? The last part of the analysis will examine the politics behind The Revolution. Is the concept of Filipinas, and consequently Filipinos, just a fluke?

Delgado makes an astute observation, "[Mata] is set up for tragedy. Given so much but so little, while inside the ideal world of the academe, he becomes too smart for his own circumstances; he is forever misplaced" (Apostol, Interview 294). The ending of The Revolution presents the reader with certain problems especially in terms of Raymundo Mata as a figure of historical agency. Mata, as character, belies the problems of a theoretical discourse or a literary text that only finds legitimacy in a discursive space. If Raymundo Mata cannot find agency outside textuality, does this imply that The Revolution fails in its project of reimagining or reinscribing nationhood? Is there no way out of the text that finds itself in a loop with the same beginnings and no ends? (Apostol, The Revolution 270)

In the "Translator's Notes" section, Magsalin describes Mata: "The man you will find in the manuscript has no approximate precursor in the annals of the revolution, perhaps even of humankind" (Apostol, The Revolution 6). This description leads one to question the viability of Mata in representing any form of subjugated identity. Espejo notes, "Raymundo, as a petty-bourgeois Basque-Filipino-(ghostChinese) quadroonish type, from landowning, military lamp-oil-selling castes, is, 
I'm sorry to say, destined to mess up" (Apostol, The Revolution 109). The plurality of his existence leads one to assume that he exists everywhere and, therefore, also nowhere. His diffused identity misplaces him and relegates him to the margin and not because this is the strategic position to be in, but because there is no other place where he can belong.

Dr. Drake also comments on Mata's ancestry, "isn't it both a generic and symbolic marvel that Mata contains within himself the Enemy, his ancestor Matta, so that the Self 'like a vertiginous Russian doll concatenates into a delirium of recuperated animosities, a precious history of revulsion' out of which truth erupts?" (Apostol, The Revolution 24) What Dr. Drake implies is that for Rizal to remain untainted, there must necessarily exist an Other to whom all things punny and funny about Rizal can be attributed to; thus, Mata becomes an overdetermined subject where everything negative is placed. This becomes less a critique of Mata than an upholding of the irreproachable status of Rizal. Benita Parry writes that Bhabha, in "representing the productive tensions of its own situation as normative and desirable, the privileged postcolonial is prone to denigrate affiliations to class ethnicity" (71). Indeed, the heterogeneous socio-economic class of Mata becomes a disadvantage; hybridity is not always to be desired.

In addition to Mata's diverse social class, his function as reader is also problematic. Mata is the ideal reader, one with a photographic memory as well as an ability to make connections between what he reads and the prevailing circumstances of his time. In Entry \#40, Magsalin footnotes an exchange between Fr. Gaspar and Mata where the former says, "Nothing exists without an observer" (Apostol, The Revolution 237). Indeed, Mata is the ideal observer, keen and sensitive but never antagonistic, only agonized by his inability to be recognized as a writer. However, by choosing to elevate Mata to an ideal reader, Apostol removes him from any subject-position. For Mata to exist in the level of the real or to gain materiality, he must exist beyond words, but he can't, "I don't know what it is about me that I contain nothing but semen and words" (Apostol, The Revolution 239).

Not only does Mata have a difficulty existing beyond words, but his love for reading also, ironically, proves to be a deterrent in his accidental role as a revolutionary. He writes in one of his final entries, "I'd rather fuck a leper than go to war. That's just common sense. I know, I know-the Spaniards were our enemies. But the thing is, I'm just not a killer ... Really, I'm just a reader" (Apostol, The Revolution 244). The anti-confrontational stance of Mata shows his inability to exist in a space that is material. With the imminent attack of Spanish civil guards at the Katipunan's camp, Mata buries himself under a banyan tree and imagines the tree telling him "Because encryption is a way of burying" (Apostol, The Revolution 256). Apostol, thereby, encrypts or en-crypt Mata and buries him in a textual field with no hope of escaping.

What perhaps becomes the most difficult part to comprehend in The Revolution is the mystery surrounding the Mata Papers. Dr. Drake ends her epigraph with a 
petition, "And so I demand in the name of Raymundo Mata: habeas corpus. Give us the body" (Apostol, The Revolution 277). Towards the end, even the historical or physical existence of Mata is questioned. Dr. Drake continues, "Or is it possible that the Translator, the pseudonymous Mimic, has had us in the trap of her infernal arts all along, and history is only the blind alley of her imagination?" (Apostol, The Revolution 278) What is implied with the realization that everything was a creation of the translator? It seems to show that History was still written from the perspective of the elite and educated class from where Magsalin hails. The fact that Magsalin sends a postcard stating that everything is true does not guarantee that it actually is. Does one take the translator for her word? Another critique of Bhabha by Parry is in the former's reliance on linguistic difference. She writes, "For rather than positing the capacity of theories to constitute multiple understandings of reality, and which in turn inform diverse plans for human action, Bhabha's methodology renders this reality dependent on the knowledge produced by critical discourse." She continues, "what [Bhabha] offers us is The World according to the Word" (59). This is precisely what occurs in The Revolution where the world of Mata becomes dependent and contingent on the word of what could possibly be an intellectually complicit translator, putting us back right where we started which is the conundrum of Philippine postcoloniality: the misrepresentation and underrepresentation of marginalized figures.

Aside from the possibility that Mata was, in fact, the result of an over-active imagination of a translator, there is also the problem of how The Revolution can be accessed by readers who do not have a background in literary criticism. The textual acrobatics of the novel and consequently its deconstructive tendency can only be fully appreciated by someone who has a profound knowledge of theory and world literature. Citing Voltaire and Eugene Sué further distances Mata from his contemporaries. The de-doxifying tendencies of the text will only be effective if one is able to understand how psychoanalysis and structuralism have been traditionally conceived. Even Hutcheon recognizes such intellectually complicitous critique when she says "that here exists a real threat of elitism or lack of access in the use of parody in any art" (Politics 101). At the end of the day, one can say that though there is a revisionist tendency in The Revolution, its very methods of doing so not only remains at the textual level, but also within the narrow confines of the academe. Even the interpretation and footnotes of Dr. Drake and Magsalin, which supposedly enlighten the reader, further complicates the text and are sometimes much harder to understand than the cryptic and "punny" notes of Mata. An example of this is already present in Entry \#1 where Dr. Drake explains Mata's abecedary game through psychoanalysis: "globular shapes are classic imago of the pre-mirror stage ... the reference to the father is an obvious (and, to be honest, banal) allusion to The Father" (Apostol, The Revolution 36). The obvious allusion to "The Father" is not as common as the psychoanalyst conceives. Here we also see that to a certain extent there is a specific audience that Apostol has in mind, one that can 
understand the banality or absurd nature of such an allusion. Towards the end of Entry \#2, Magsalin footnotes a juvenile poem in the Balagtas style that Mata wrote, "I was ashamed to translate his imbecility. However, Raymundo accomplishes what he sets out to do-illustrate in sweating, panting rhyme the sweating, panting act - and while the onomatopoeia is barbarous, the achievement is clear" (Apostol, The Revolution 45). Magsalin's embarrassment illustrates the distance between the figure she wishes to represent (or at least make accessible to others) and her own intellectual background. Here we see that Magsalin and Dr. Drake's attempt at allowing Mata to speak (even going to the extreme of saying "shh!" to Espejo) is merely an act of tokenization, an empty often politically correct gesture, as it were. Dr. Drake, in particular, gains psychoanalytical legitimacy in Mata; she is the least critical of Mata. However, her reading of Mata is always reduced to the level of self, determined by his search for his father.

The project of The Revolution is to poke fun at History and thereby make room for histories, yet no histories really emerge. The book is a series of deadends, malapropisms of the tongue, jokes upon jokes that destroy/annihilate, but do not create or recoup. Kumkum Sangari writes, "The writing that emerges from this [ambivalent] position, however critical it may be of colonial discourses, gloomily disempowers the 'nation' as an enabling idea and relocates the impulses for change as everywhere and nowhere" (183). Indeed, what Apostol has shown in The Revolution is the ease by which one can imagine an alternative nation and how easily one can fall into the trap of a continuous inscribing of a nation. How this nation can emerge from textuality remains unanswered. Like the specter of Philippines in Rizal's two novels, the Filipinas of Apostol remains a far-flung albeit extremely attractive ideal.

\section{Conclusion}

Gina Apostol's The Revolution makes a compelling case for the contingency of historiography. As a postcolonial text, it imagines a nation built upon the reemergence of marginalized voices and a revisioning of History. The novel, in itself, performs the nation at the moment of its production through the critics' interpretation of Mata as well as their reading of each other. Present in all her characters especially Father Gaspar, Tio U., and Matandang Leon are the symptoms of historical silencing. However, by making these figures peripheral to Mata, Apostol is unable to explore the possibility of such figures as agents for revisioning History. Furthermore, the dialogic nature of the text simultaneously asserts and effaces Filipino identity. If Rizal creates Mata in order to write Makamisa, who is actually the comic character? Is the joke aimed at Rizal or at Mata?

Such conundrums and contradictions are never resolved in the novel precisely because Apostol's method is primarily deconstructivist. In the face of Bhabha's 
formation of postcolonial theory, Apostol's "playful" approach finds legitimacy. On the level of the theoretical and the ideal, The Revolution does as expected of it. There are space-clearing gestures, an inter-mingling of voices, and the shift from the pedagogical to the performative. However, in applying Parry's materialist critique, one realizes that it is not enough to remain in the realm of textuality and discursivity. Mata as a character is problematic not because he fails to represent subjugated identities, but because one cannot conceive of a Mata outside the novel. The Revolution is symptomatic of the innate problems that plague Philippine postcoloniality. The distance between the deconstructivist approach of Bhabha and the material inclinations of Parry seem to suggest the impossibility of a reconciliation. In light of this, how should postcolonialisim in the Philippines be studied and written?

The Revolution shows the necessity of a mediated and a critically-anxious position in the discourse of postcoloniality. It is not enough that free-play occurs within the text, but at the same time, to focus solely on material conditions of production will result in problems of economic determinism. Postcolonial studies in the Philippines should not be relegated to an either/or position of material or discursive scholarship. Philippine postcolonial discourse must straddle the lines of the conditions of productions and discursive formations. Such an endeavor does not have a fixed methodology, but the questions that The Revolution raise is a firm starting point.

It should be concluded that Apostol's The Revolution has cleared the way towards a more refined understanding of historiography, and from there we must pursue a new kind of investigative practice. The difficulties inherent in reading about the past and writing about it should not be a detriment towards a search for an escape from a debilitating colonialist system of knowledge. Not only should we look at History from a new perspective, but see theory in all its (im)possibilities.

\section{Works Cited}

Agoncillo, Teodoro. History of the Filipino People. 8th ed. Quezon City: Garotech, 1990. Print.

Anderson, Benedict. "Cultural Roots." Imagined Communities: Reflections on the

Origins and Spread of Nationalism. Revised ed. London: Verso, 2006. Print.

Apostol, Gina. The Revolution According to Raymundo Mata. Pasig City: Anvil, 2009.

Print.

—. "Interview with Gina Apostol." Interview by Daryll Delgado. Kritika Kultura 15

(2010): 284-96. Web. 5 July 2011.

Bhabha, Homi K. The Location of Culture. Oxon: Routledge, 1994. Print. 
Introduction. Nation and Narration. Ed. Homi K. Bhabha. London: Routledge, 1990. 1-7. Print.

Derrida, Jacques. "Structure, Sign, and Play in the Discourse of the Human Sciences." Writing and Difference. Trans. Alan Bass. Oxon: Routledge, 2001. 351-70. Print.

Hau, Caroline S. "Literature and History." Necessary Fictions: Philippine Literature and the Nation, 1946-1980. Quezon City: Ateneo de Manila UP, 2000. 94-132. Print.

Hutcheon, Linda. The Politics of Postmodernism. New York: Routledge, 2002. Print.

- "Historiograhic Metafiction: Parody and the Intertexts of History." Intertextuality and Contemporary American Fiction. Eds. P. O'Donnell and Robert Con Davis. Baltimore: Johns Hopkins UP, 1989. 3-32. Print.

Laurel, R. Kwan. "A Hundred Years after the Noli: The Three Centennial Novels in English." Philippine Studies 51 (2003): 599-643. Print.

Ocampo, Ambeth. The Search for Rizal's Third Novel Makamisa. Quezon City: Anvil, 1992. Print.

Parry, Benita. Postcolonial Studies: A Materialist Critique. Oxon: Routledge, 2004. Print.

Said, Edward. Orientalism. New York: Vintage, 1979. Print.

Sangari, Kumkum. "The Politics of the Possible." Cultural Critique 7 (1987): 157-86. JSTOR. Web. 3 Feb. 2012. 